\title{
PDUI (PLANO DE DESENVOLVIMENTO URBANO INTEGRADO): PRIMEIROS ASPECTOS, COMPARAÇÕES, CRÍTICAS, CONCLUSÕES, RELAÇÕES E EXPERIÊNCIAS APÓS 03 (TRÊS) ANOS DE SUA CRIAÇÃO LEGAL
}

PDUI (INITIALS IN PORTUGUESE) INTEGRATED URBAN DEVELOPMENT PLAN: FIRST ASPECTS, COMPARISONS, CRITICISMS, CONCLUSIONS, RELATIONS AND EXPERIENCES AFTER 03 (THREE) YEARS OF ITS LEGAL CREATION

\section{Luigi Bonizzato ${ }^{1}$ \\ Isabelle Esteves Moulin²}

\section{Resumo}

O presente Artigo jurídico volta-se para o estudo do Plano de Desenvolvimento Urbano Integrado (PDUI), criado no país por meio do Estatuto da Metrópole, mais precisamente, pela Lei 13.089, de 12 de janeiro de 2015. Trata-se de um plano urbanístico, de competência legislativa dos Estados membros da Federação brasileira, dentro dos quais localizam-se as chamadas regiões metropolitanas brasileiras. Em dois capítulos, faz-se uma abordagem qualitativa dos dois mais importantes planos urbanísticos brasileiros, o acima citado PDUI e o Plano Diretor municipal, mas com foco sempre mais direcionado àquele plano. Aproximados 03 (três) anos após a entrada em vigor do Estatuto da Metrópole e da instituição do prazo de também 03 (três) anos para a criação do Plano de Desenvolvimento Urbano Integrado (PDUI) pelos Estados, para suas regiões metropolitanas, análises quantitativas também embasaram variadas conclusões, pautadas, paralela e, preponderantemente, em pesquisa que se valeu de método dedutivo para seu desenvolvimento e conclusões, assim como de fontes bibliográficas e legislativas.

\footnotetext{
${ }^{1}$ Doutor em Direito pela Universidade do Estado do Rio de Janeiro (UERJ). Professor Associado de Direito e do Programa de Pós-Graduação stricto sensu em Direito da Universidade Federal do Rio de Janeiro (UFRJ). Integrante do LETACI/FND/UFRJ (Laboratório de Estudos Teóricos e Analíticos sobre o Comportamento das Instituições), que se encontra vinculado à Faculdade de Direito da UFRJ e à linha de pesquisa do PPGD/UFRJ intitulada "Democracia, Instituições e Desenhos Institucionais". Membro da Comissão de Direito Ambiental da OAB/RJ. E-mail: bonizzato@bonizzato.com.br.

2 Graduada em Direito pela Universidade Federal do Rio de Janeiro - FND/UFRJ (Brasil). Monitora de Direito Constitucional nos anos 2015/2016/2017 na FND/UFRJ (Brasil). Pesquisadora do LETACI/FND/UFRJ (Laboratório de Estudos Teóricos e Analíticos sobre o Comportamento das Instituições), que se encontra vinculado à Faculdade de Direito da UFRJ e à linha de pesquisa do PPGD/UFRJ intitulada "Democracia, Instituições e Desenhos Institucionais". E-mail: belle.moulin@gmail.com.
} 
Palavras-Chaves: Plano de Desenvolvimento Urbano Integrado (PDUI); Estatuto da Metrópole; Plano Diretor; Constituição; regiões metropolitanas.

\begin{abstract}
The present paper is committed with the study of the Integrated Urban Development Plan (PDUI, initials in Portuguese), created in the country through the Metropolis Statute, more precisely, by the Law 13.089, of January 12th, 2015. It is an urban plan, of legislative competence of the member states of the Brazilian Federation, within which are located the socalled Brazilian metropolitan regions. In two chapters, there is a qualitative analysis of the two most important Brazilian urban plans, the aforementioned PDUI (initials in Portuguese) and the municipal Director Plan, but always focusing on the first. Approximately 03 (three) years after the entry into force of the Metropolis Statute and the establishment of a period of 03 (three) years for the creation of the Integrated Urban Development Plan (PDUI, initials in Portuguese) by the member states, for their metropolitan regions, quantitative analyses also supported a number of conclusions, based on, in parallel and, predominantly, a research that used a deductive method for its development and conclusions, as well as bibliographical and legislative sources.
\end{abstract}

Keywords: Integrated Urban Development Plan (PDUI, initials in Portuguese); Metropolis Statute; Director Plan; Constitution; metropolitan regions. 


\section{INTRODUÇÃO}

A entrada em vigor do Estatuto da Metrópole, praticamente 14 (quatorze) anos após a criação e início de vigência do Estatuto da Cidade, respectivamente, Leis 13.089/2015 e 10.257/2001, representou não somente a certeza de que o Estatuto da Cidade, mesmo com inúmeros problemas relativos à aplicabilidade de alguns institutos, continua firme em seus propósitos e em sua crescente aceitação social e, principalmente, institucional, mas também a conviç̧ão de que a preocupação com o espaço urbano não se esgotou na figura somente, repita-se, do Estatuto da Cidade. Um outro Estatuto chegou e com foco, igualmente, nas problemáticas de cunho urbano.

Assim, conforme se verificará durante o texto, um dos mais relevantes institutos trazidos pelo Estatuto da Metrópole foi o chamado Plano de Desenvolvimento Urbano Integrado (PDUI), voltado para a regulação do ordenamento territorial das denominadas regiões metropolitanas brasileiras. Desse modo, um Plano de maior abrangência se comparado ao Plano Diretor, para o qual atenções também são direcionadas no texto principal e, da mesma forma, de maior hierarquia, de acordo com as próprias previsões contidas na Lei 13.089/2015.

Nesse sentido, o Brasil deve celebrar, ainda que com prudência, responsabilidade e tão necessárias críticas, a possibilidade de se pensar, organizar e desenvolver urbanisticamente de modo mais articulado, amplo e planificado. A tipificação de mais um plano urbanístico, o Plano de Desenvolvimento Urbano Integrado (PDUI), por meio de mais uma lei federal e de eficácia nacional (Estatuto da Metrópole), seguindo o exemplo do Estatuto da Cidade, traz à tona a magnitude de princípios de planos urbanísticos, tais como o da hierarquia, articulação e tipicidade, vocábulos já, inclusive, naturalmente presentes e mencionados nesta introdução.

Enfim, o momento para a realização e concretização da presente pesquisa é estratégico, pois coincidente com o prazo inicial e, no início de 2018, ampliado por alteração do Estatuto da Metrópole, de 03 (três) anos para a elaboração, por cada Estado detentor de região 
metropolitana, do seu Plano de Desenvolvimento Urbano Integrado (PDUI). Frise-se, embora tenha havido um aumento de prazo, que pode chegar até o ano 2021, não tivesse sido a Lei 13.89/2015 modificada, quantos Estados e regiões metropolitanas teriam cumprido seu dever legal?

Tudo isto será abordado nas linhas subsequentes.

\section{PLANO DIRETOR E SEUS DESDOBRAMENTOS CONCEITUAIS E INSTITUCIONAIS SOB A ÉGIDE E CHEGADA DO PLANO DE DESENVOLVIMENTO URBANO INTEGRADO (PDUI)}

O Plano de Desenvolvimento Urbano Integrado (PDUI), introduzido e inaugurado no ordenamento jurídico brasileiro pelo Estatuto da Metrópole, Lei 13.089, de 12 de janeiro de 2015, após poucos anos contados de sua chegada, já aponta para a necessidade de acompanhamento contínuo de sua evolução, máxime política e jurídica. A pesquisa que resultou na consecução das linhas seguintes culminou em resultados que demonstram que nem todas as regiões metropolitanas do país simplesmente ignoraram o lançamento legislativo, ainda mais sob a égide de um largo e estendido prazo para sua concretização. Já se registram avanços, mas que devem ser monitorados, avaliados e examinados, a fim de que se possa verdadeiramente mapear uma evolução da implantação de tão rico instituto no país.

Paralelamente, a chegada de um novo plano urbanístico, fora da esfera constitucional, mas de magnitude ímpar, sobretudo por (a) reforçar o caminho de fortificação da figura de planos urbanísticos em um país sem tradições, principalmente jurídicas, de planos desta natureza; (b) conter relação direta com o único plano urbanístico constitucionalizado em 1988, o Plano Diretor; e (c) abrir espaço para novos horizontes de planejamento urbanístico, com base não somente em políticas urbanas e na consecução de urbanizações decorrentes do urbanismo enquanto ramo do saber, mas também e, principalmente, com base em um verdadeiro e mui rico Direito Urbanístico, torna o Plano de Desenvolvimento Urbano Integrado (PDUI), um verdadeiro instituto, ator e elemento a ser atentamente acompanhado em seu percurso criacional e aplicacional.

De todo modo, tendo em vista que o Plano de Desenvolvimento Urbano Integrado (PDUI) possui relação direta com o Plano Diretor enquanto também instituto do Direito Urbanístico, a análise de ambos far-se-á necessária para que possam ser atingidas conclusões aqui reputadas minimamente adequadas. Por isso, um estudo atual do Plano Diretor ocorrerá 
para, na mesma toada, chegar-se a uma também contemporânea abordagem do Plano de Desenvolvimento Urbano Integrado (PDUI).

Assim, o exame do Plano Diretor é entendido como de extrema importância, ainda mais em um Artigo que sinaliza para a próxima relação entre planos urbanísticos, ordem urbana, Constituição da República e Leis infraconstitucionais que referendam a relevância dos referidos planos e, por conseguinte, da chamada ordenação do território brasileiro. E, como um dos próprios nomes e elementos já indicam, fala-se, por exemplo, em ordem e, não, em "desordem" urbana. Por isso, planos urbanísticos detêm grande importância para o desenvolvimento de cidades, aglomerações destas e, por consequência lógica, de um próprio país aonde se encontrem quaisquer umas localizadas.

Paralela e ilustrativamente ao apenas mencionado, é bastante comum que vários países sejam, ainda que superficialmente, avaliados a partir de uma ou de poucas mais cidades. Sobretudo nações com territórios ou populações não muito extensos, findam por ter cidadeschaves, as quais são o principal reflexo interno e externo de determinado país. Dessa forma, como não conceber Sydney como a grande referência interna e externa da Austrália ${ }^{3}$, enquanto nação? O mesmo valendo para Buenos Aires, como referência para a Argentina; Santiago para o Chile; Paris para a França, entre outros tantos exemplos. Portanto, preocupar-se com a ordem urbana de uma cidade, pode significar, sim, uma preocupação com um país no seu todo.

Vale também lembrar, em breve recuo temporal que, carente de uma adequada normatização urbanística e, por consequência ou como causa, também de uma tradição de planos urbanísticos, as esperanças de planejamento urbano, no final do século passado e início deste novo século foram depositadas em cima do Plano Diretor. Segurança, transporte, moradia, lazer, entre tantos direitos ligados às regiões urbanas e, a cada dia, mais ardorosamente pleiteados pela população brasileira, findam por estar diretamente relacionados ao Plano Diretor. Por exemplo, já na segunda década do século XXI, quando o Brasil - e, de modo mais preciso, suas cidades -, sediaram os dois maiores eventos esportivos do planeta, várias reformas urbanas essenciais passaram a formalmente depender deste único plano urbanístico, constitucionalmente previsto e de competência municipal ${ }^{4}$. $\mathrm{O}$ advento do Estatuto

\footnotetext{
${ }^{3}$ Valendo lembrar que Sydney sequer é a capital da Austrália. Camberra é a capital deste país.

${ }^{4}$ Embora sejam aqui citados a Copa do Mundo de Futebol da FIFA de 2014 e os Jogos Olímpicos de 2016, as atenções deste Artigo não se deterão a tais eventos. E cabe ainda acrescentar o maior evento esportivo das Américas, ocorrido no ano de 2007: os Jogos Pan Americanos, em relação ao qual servem os mesmos comentários acima feitos.
} 
da Metrópole, em janeiro de 2015, não ocorreu a tempo de poder significar um mínimo auxílio de planificação na empreitada salientada.

Reforce-se, ainda, que em diversos países do ocidente, a existência de planos urbanísticos variados acompanhou a evolução e o desenvolvimento urbano de suas principais cidades. Entretanto, conforme anunciado, não se reservou a apenas um principal plano a tarefa árdua e inglória de ditar os rumos urbanos de várias regiões. Múltiplos planos, aplicados e utilizados conjuntamente, serviram sempre de base para a criação de infraestrutura, equipamentos urbanos e melhorias urbano-sociais. Planos às vezes nacionais, regionais, estatais e locais - fazendo-se aqui proposital paralelo com a estrutura político-federativa nacional estabeleceram os nortes do desenvolvimento urbano em vários países desenvolvidos ${ }^{5}$. Mas esta não foi a realidade no Brasil.

A Constituição nacional surgiu como atuante e portadora de um papel fundamental, pois uma mera previsão em seu texto da figura do Plano Diretor adquiriu força normativa a se respeitar, se analisado o histórico constitucional pós-1988. A extensão e pluralidade de direitos, garantias e deveres da Constituição brasileira de 1988, se em um primeiro momento criticadas ou colocadas sob descrenças, hoje levam, também, à obtenção de vantagens pela sociedade em geral, que vê uma série de institutos talvez fadados ao esquecimento ganharem em força e importância. E o Plano Diretor, em conformidade com o que já se vem repetindo, é um exemplo claro deste aumento de relevância e de atenção conferido a partir de sua previsão constitucional. Ainda que haja muito a ser feito, já não é difícil identificar avanços em seara urbanística, em razão da inserção e manutenção na Constituição do Plano Diretor. E que se some a isto a chegada, principalmente, do Estatuto da Cidade, complementador na esfera infraconstitucional, mesmo que 13 (treze) anos depois da promulgação da Constituição de 1988.

Nesse viés, o Brasil, embora tímido na previsão e organização legal e constitucional em matéria de planos urbanísticos, pelo menos, teve estampada em sua Constituição vigente a figura do Plano Diretor. Para além do previsto no Art. 182 da Constituição da República, juntamente com o Art. 183, do Capítulo II, do Título VII, do texto constitucional, dedicados à chamada, pelo legislador constituinte, "Política Urbana", o Plano Diretor é pelos ora Autores

\footnotetext{
${ }^{5}$ Para um exame aprofundado, que escapa das preocupações diretas deste Artigo, sugere-se conferir os Livros "Propriedade Urbana Privada \& Direitos Sociais: 2a Edição - Revista e Atualizada, incluindo a Lei 13.089/15, que instituiu o Estatuto da Metrópole" (BONIZZATO, 2015) e "Constituição, Democracia e Plano Diretor, sob o influxo de direitos sociais e de liberdade, políticas estatais e institucionais" (BONIZZATO, 2014).
} 
conceituado, de forma ainda vestibular, como uma lei complementar municipal, portadora de normas gerais específicas, com o objetivo de regular a ordenação do território, em prol da consolidação de ordens urbanas e, por conseguinte, da promoção de princípios variados, de inúmeros ramos do Direito, mas, principalmente, de Direito Urbanístico, como o bem-estar social, a sustentabilidade, a qualidade de vida, a dignidade urbana, a função social da propriedade e, entre outros, o princípio da função social da cidade.

Com efeito, o Plano Diretor, antes de tudo, é uma lei de natureza complementar. Lembre-se que o Art. 59 da Constituição da República traz o rol de espécies normativas, anunciando o chamado processo legislativo federal ${ }^{6}$. Assim, Emendas à Constituição, medidas provisórias, leis ordinárias e, entre outras, leis complementares, são espécies normativas, no Brasil. Enquanto uma lei ordinária é, em breve resumo, a que pode ser aprovada pela chamada maioria simples ou relativa, a lei complementar é a que somente pode ser aprovada pela maioria absoluta dos membros de uma Casa Legislativa. Paralelamente, enquanto uma lei complementar, de acordo com o citado processo legislativo federal, tem campos materiais a ela destinados pela própria Constituição de 1988, a lei ordinária é aquela sobre a qual recairão todas as matérias residuais, exatamente por isso, a espécie normativa mais comum e mais elaborada no Brasil.

Nesse sentido, tendo em vista que, em aplicação ao princípio da simetria, Estados e municípios devem seguir as bases do processo legislativo federal, a lei complementar pela qual se criará o Plano Diretor também deverá ser aprovada pela maioria absoluta dos membros da Câmara dos Vereadores ou Municipal. Em dizeres mais precisos, o Plano Diretor será uma lei complementar e, por isso, aprovado por maioria absoluta, de acordo com o que dispuser cada Lei Orgânica, de cada município brasileiro. E são, normalmente, estes municípios que, em suas Leis Orgânicas, trazem a obrigatoriedade expressa de o Plano Diretor ser veiculado por meio de uma lei complementar, e não ordinária; fato com o que ora não se está de acordo, pois se entende que seria mais adequado que a Constituição ou uma lei federal (no caso, o Estatuto da Cidade, Lei 10.257/2001) trouxessem esta obrigatoriedade, vinculando, desta forma, todos os municípios do país e, ao mesmo tempo, dissipando quaisquer eventuais dúvidas sobre qual a natureza jurídica, de caráter normativo, do Plano Diretor, assim como suprindo eventuais omissões pelos legisladores constituintes derivados decorrentes, em âmbito municipal.

\footnotetext{
${ }^{6}$ Eis o teor do Art. 59 da Constituição de 1988: “Art. 59. O processo legislativo compreende a elaboração de: I - emendas à Constituição; II - leis complementares; III - leis ordinárias; IV - leis delegadas; V medidas provisórias; $\mathrm{VI}$ - decretos legislativos; VII - resoluções".
} 
A título exemplificativo, a Lei Orgânica do Município do Rio de janeiro, em seu Art. 70, parágrafo único, estabelece que são leis complementares, entre outras previstas na referida Lei Orgânica, o Plano Diretor da cidade 7 . E a Lei Orgânica do Município de São Paulo, na linha da discordância que apenas se salientou, de forma ainda mais rígida e sequer fazendo menção à natureza jurídica da lei que veiculará o Plano Diretor, assim determina em seu Art. 40, § 4o: "Dependerão do voto favorável de 3/5 (três quintos) dos membros da Câmara as seguintes matérias: I - zoneamento urbano; II - Plano Diretor; III - Zoneamento geo-ambiental. (Acrescentado pela Emenda 20/01)". Como foi o quórum exigido ainda mais rígido, aqui se entende que não entra em choque com a pretensão do legislador constituinte originário que criou a Constituição de 1988. Afinal de contas, abundar em rigor para uma tão importante lei, como é a que traz o Plano Diretor não é aqui encarado como problema e, tecnicamente, também como qualquer inconstitucionalidade. De todo modo, aqui se reafirma e fixa o entendimento segundo o qual o Plano Diretor é (ou deve ser) uma lei complementar municipal.

Para além das considerações já realizadas, foi também dito acima que o Plano Diretor é uma lei portadora de normas gerais específicas. Um paradoxo aparente, mas a ser agora explicado. O Plano Diretor é, sim, uma lei que possui, preponderantemente, normas gerais sobre matéria urbanística, mais precisamente, sobre desenvolvimento urbano e, de forma ainda mais precisa, sobre a ordenação do território de um município. Não é adequado que um Plano Diretor, por exemplo, traga uma norma de especificidade tal que venha a comprometer a mínima abstração que toda lei deve possuir. Assim, citações de ruas, especificação de calçadas, entre outras tantas especificidades, devem ser evitadas em um Plano Diretor. Até porque, o Plano Diretor deve fornecer as diretrizes e vetores gerais para um possível crescimento urbano local e ser complementado por leis municipais ordinárias, que serão mais específicas do que o Plano Diretor, mas, igualmente, sem qualquer perda da mínima abstração legal, assim como complementado, final e, eventualmente, por decretos regulamentares emitidos pelo Poder Executivo. Portanto, se recortado e considerado um determinado município brasileiro de forma isolada, o Plano Diretor será um portador de normas gerais sobre as matérias a ele inerentes.

\footnotetext{
${ }^{7}$ Assim estatui o Art. 70 e parágrafo único, da Lei Orgânica do Município do Rio de Janeiro: “Art. 70 - As leis complementares serão aprovadas por maioria absoluta, em dois turnos, com intervalo de quarenta e oito horas, e receberão numeração distinta das leis ordinárias. Parágrafo único - São leis complementares, entre outras previstas nesta Lei Orgânica: I - a lei orgânica do sistema tributário; II - a lei orgânica do Tribunal de Contas do Município e de sua Procuradoria Especial; III - a lei orgânica da Procuradoria-Geral do Município; IV - o estatuto dos servidores públicos do Município; V - o plano diretor da Cidade; VI - a lei orgânica da Guarda Municipal; VII - o código de administração financeira e contabilidade pública; VIII - o código de licenciamento e fiscalização; IX - o código de obras e edificações".
} 
Por outro lado, o Plano Diretor pode também ser reputado um portador de normas específicas. Dessa forma, quando a Lei 10.257/2001, ou seja, o Estatuto da Cidade, tornou-se a lei infraconstitucional complementadora da Constituição de 1988 em matéria urbanística, suprindo a limitação inicial do Art. 182, que sempre exigiu a criação de uma lei portadora de diretrizes gerais ("conforme diretrizes gerais fixadas em lei") e atendendo a vários outros dispositivos da própria Constituição, deixou ainda mais clara a natureza específica a que, neste momento, se refere. Em inúmeras ocasiões, o referido Estatuto da Cidade trouxe institutos e instrumentos de política urbana, em relação aos quais fez depender a criação, no âmbito municipal, de Planos Diretores e leis municipais, a fim de que o instituto ou instrumento lá previsto pudesse adquirir verdadeira e real eficácia e aplicabilidade no mundo fático. Entre múltiplos exemplos, o $\S 1$ 으, do Art. 25, do Estatuto da Cidade, ao tratar do chamado direito de preempção (direito de preferência), estabeleceu que "lei municipal, baseada no plano diretor, delimitará as áreas em que incidirá o direito de preempção e fixará prazo de vigência, não superior a cinco anos, renovável a partir de um ano após o decurso do prazo inicial de vigência". Perceba-se, mesmo com a complementação trazida pelo Estatuto da Cidade, o instrumento de política urbana denominado direito de preempção, entre outros que poderiam ser aqui citados, somente pode ser realmente aplicado se um município criar, respectivamente, seu Plano Diretor e subsequente lei municipal. Em um primeiro momento, ocorreu uma espécie de transferência de responsabilidade complementadora do Art. 182 e demais dispositivos constitucionais sobre matéria urbanística para o legislador não mais federal, mas do 3o grau federativo brasileiro, ou seja, o municipal. De qualquer maneira, visualizado o Plano Diretor a partir de uma leitura da Constituição, do Estatuto da Cidade ou, até mesmo, de Constituições Estaduais e Leis Orgânicas Municipais, não restam dúvidas de que o Plano Diretor será um portador de normas específicas e relativas ao município que o criou.

Por conseguinte, o paradoxo apresentado é aqui reputado como conceitualmente muito útil, a fim de se explicar uma dúplice nuança do Plano Diretor: é ele um portador de normas gerais e específicas. Tudo a depender do ponto de vista, do referencial escolhido para sua análise, enfrentamento, criação e aplicação.

Em sequência, imperioso também explorar a ideia de que o Plano Diretor tem por objetivo regular a ordenação do território, em prol da consolidação de ordens urbanas e, por corolário, dos próprios princípios que regem o Direito Urbanístico. O território, não somente em sentido estrito ou geograficamente considerado, mas também em seu sentido amplo, que vai incluir, para além de delimitações numéricas, especificações urbanísticas, dentro das quais 
inúmeros direitos sociais terão que ser considerados, questões políticas e econômicas, e sob a égide de um rigoroso olhar jurídico.

Logo, ordenar o território é função marcante do Plano Diretor, mas com base em elementos como prestação de serviços públicos à população, atendimento a interesses econômicos não conflitantes com direitos sociais e outros fundamentais básicos, assim como, entre outros, respeito aos princípios básicos de Direito Urbanístico, a maioria dos quais diretamente ligados ao que se justamente acabou de elencar. O Direito Urbanístico enquanto ramo autônomo do Direito encontra um dos seus maiores alicerces no Direito Constitucional, uma vez que impensável sem a conexão constante com os direitos sociais mais básicos, previstos na Constituição brasileira e, apenas para se fazer um paralelo, em várias Constituições de países desenvolvidos, em desenvolvimento e mesmo subdesenvolvidos.

Vale, entretanto, ressaltar que os planos urbanísticos, dos quais é um exemplo o Plano Diretor, devem zelar pelo que foi supramencionado. E, mesmo sendo planos urbanísticos de maior hierarquia, sobretudo em casos de países que possuem várias previsões legais e respectivas aplicações práticas de uma cadeia de planos. No caso brasileiro, a chegada, principalmente, do Estatuto da Metrópole, conforme acima já explanado, com a previsão do Plano de Desenvolvimento Urbano Integrado (PDUI), hierarquicamente superior ao Plano Diretor e de competência dos Estados membros da Federação, faz com que tanto um Plano (o Diretor), quanto o outro (o de Desenvolvimento Urbano Integrado), tenham que respeitar os direitos sociais e demais fundamentais aplicáveis ao ambiente e às relações urbanas, de forma implacável.

Aproveite-se o momento para deixar bem claro que os princípios de Direito Urbanístico a que se fez menção não se confundem com princípios de planos urbanísticos nem, muito menos, com princípios de urbanismo. Uma tradicional confusão que já vai se tornando, cada dia mais, equívoco de um passado sempre mais distante. Princípios do ramo do saber chamado Urbanismo são voltados a ele, e não à seara jurídica que é o ponto central de análise neste Artigo. Os princípios de planos urbanísticos são variados, embora um pouco mais relevantes do ponto de vista jurídico, se comparados com os princípios do Urbanismo, dos quais, de forma alguma, retira-se a importância, mas devem ser bem localizados para que não interfiram em um correto exame, frise-se, eminentemente jurídico.

Nessa perspectiva, serão elencados 03 (três) princípios de planos urbanísticos, a título de mera ilustração neste breve texto: o da hierarquia, e o da articulação e o da tipicidade. 
Todos de magnitude jurídica ímpar e com impacto, também, nas ordens social, política e econômica.

O chamado princípio da hierarquia significa que planos urbanísticos de igual hierarquia devem ser complementares ou, simplesmente, não entrar em choque, de modo a causar dúvidas quanto à incidência de cada um. Mas, principalmente, significa que planos urbanísticos de menor hierarquia devem obediência e respeito ao estabelecido em planos urbanísticos de maior hierarquia. Com o advento e achegada do Estatuto da Metrópole, tire-se, como exemplo, a relação que passou a existir entre o Plano Diretor municipal e o Plano de Desenvolvimento Urbano Integrado (PDUI), de responsabilidade criadora dos Estados membros da Federação brasileira. Aquele, isto é, o Plano Diretor, deverá se adaptar e estar em consonância com o que prevê o Plano de Desenvolvimento Urbano Integrado (PDUI). Aliás, é o que se depreende do próprio texto do Estatuto da Metrópole, que dissipa dúvidas ao estabelecer que "Nas regiões metropolitanas e nas aglomerações urbanas instituídas mediante lei complementar estadual, o Município deverá compatibilizar seu plano diretor com o plano de desenvolvimento urbano integrado da unidade territorial urbana" (Art. 10, § 3). Com menção indispensável e

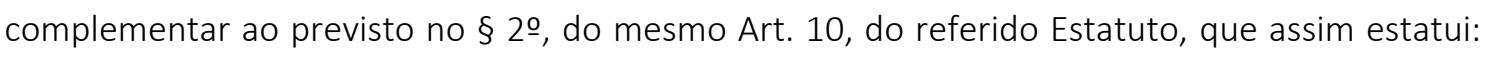
"a elaboração do plano previsto no caput deste artigo não exime o Município integrante da região metropolitana ou aglomeração urbana da formulação do respectivo plano diretor, nos termos do § 1o do art. 182 da Constituição Federal e da Lei no 10.257, de 10 de julho de 2001"8.

Além do princípio da hierarquia, cujo exemplo acima pôde já ilustrar sua incidência em território nacional, chame-se atenção, agora, para o princípio da articulação. E tal princípio também encontrará nos dispositivos acima transcritos e no próprio Estatuto da Metrópole, um vigor que, até então, não havia encontrado no Brasil. Segundo esse princípio, planos urbanísticos de igual hierarquia e, principalmente, de municípios contíguos, devem articular-se, de modo a serem complementares, a interagirem e a favorecerem uma comunicação, interrelação e complementaridade institucionais. Mais precisamente, entre instituições de mais de um município limítrofe. Em regiões metropolitanas, caracterizadas por grandes aglomerações urbanas, muitas vezes municípios se separam por meras ruas, calçadas e linhas imaginárias em um ambiente urbano, aparentemente, único. Portanto, nada mais adequado do que, por exemplo, o Plano Diretor de um município, estar em consonância com o Plano Diretor do município vizinho e vice-versa. E a existência do Plano de Desenvolvimento Urbano Integrado

\footnotetext{
${ }^{8}$ Eis o teor do Art. 10 do Estatuto da Metrópole: "As regiões metropolitanas e as aglomerações urbanas deverão contar com plano de desenvolvimento urbano integrado, aprovado mediante lei estadual".
} 
(PDUI) vem apenas fortificar tal articulação, na medida em que deve ser uma espécie de norteador hierarquicamente superior aos Planos Diretores dos municípios que integram a região metropolitana de um Estado.

Por último, o princípio da tipicidade refere-se, diretamente, à ideia de legalidade. Todos os planos urbanísticos devem estar previamente previstos em lei, ou seja, tipificados, para poderem ser criados. Nesse sentido, não se pode inventar um plano urbanístico: ou ele já está previsto em lei e, por essa razão, pode ser criado por meio de nova e outra lei, ou não há que se cogitar da criação de um plano. Tal princípio, assim, confere maior segurança jurídica às ordens urbanas, as quais terão seu desenvolvimento, crescimento e ordenação regulados por plano que goza da legalidade e da presunção de legitimidade decorrente de uma lei prévia que o previu, com o estabelecimento de suas características, funções, finalidades e bases maiores.

Com efeito, os planos urbanísticos, dos quais é espécie o Plano Diretor, assim como, também, o Plano de Desenvolvimento Urbano Integrado (PDUI), devem, pelo menos, respeito a tais princípios, cada vez mais em voga no Brasil contemporâneo e, certamente, futuro. O caminho trilhado e que continua a ser desenhado vai em direção do ganho de relevância, continuamente mais intenso, da figura destes chamados planos urbanísticos, cuja atenção maior, nestas primeiras linhas deste Artigo, sobretudo pelas razões já anteriormente apontadas, recai sobre o, até agora, único plano urbanístico previsto na Constituição de 1988, o Plano Diretor.

Nesse seguimento, não se encerrará este subtítulo sem antes serem tecidas as considerações necessárias sobre os princípios do próprio Direito Urbanístico. Função social da propriedade, sobretudo urbana, bem-estar social, sustentabilidade, qualidade de vida, dignidade urbana e, entre outros, função social da cidade, são princípios de Direito Urbanístico e sua promoção se encaixa nos objetivos centrais de um Plano Diretor.

Destarte, quando um Plano Diretor estabelece que em determinada área de um município poderão incidir alguns instrumentos de política urbana previstos, por exemplo, no próprio Estatuto da Cidade ou, até mesmo, na própria Constituição (como é o caso dos instrumentos contidos no $\S 4$ 4ㅇ, do Art. 182, da Constituição de 1988), nada mais deverá estar fazendo do que focando na ordenação do território municipal sobre as bases principiológicas acima expostas. É claro que influências variadas recaem sobre qualquer processo legislativo e diferente não seria no caso do processo de elaboração de um Plano Diretor, em torno do qual muitos interesses econômicos e políticos podem estar presentes. Mas, paralelamente, é certo, também, que uma das mais importantes finalidades de verdadeiros princípios jurídicos é a 
orientação e determinação dos rumos a serem seguidos por um ordenamento, seja ele qual for. Por conseguinte, em teoria, os princípios acima mencionados, repita-se, ente outros que poderiam ser levantados (e apenas não foram em razão do objeto deste Artigo não ser o estudo específico do Direito Urbanístico e de seus princípios), existem para nortear o trabalho executivo, judiciário e legislativo, a fim de que outros princípios maiores constitucionais, aos quais todos os princípios especificamente elencados se vinculam, sejam respeitados.

Se assim for conduzida a elaboração do Plano Diretor, com adição dos demais requisitos e características legalmente existentes, as chances de êxito nas políticas urbanas crescem substancialmente. Ainda mais quando o país já presencia e, para além mesmo disso, vivencia a chegada de um novo plano urbanístico. O Plano de Desenvolvimento Urbano Integrado (PDUI) deve dar as mãos ao Plano Diretor, de modo a promover e estimular uma interlocução regionalinstitucional capaz de forte e firmemente contribuir para a consecução de políticas urbanas em áreas onde o isolamento territorial causado pela multiplicidade de municípios é uma realidade comprometedora de um consentâneo desenvolvimento urbanístico.

Nesse viés, no subtítulo seguinte os holofotes voltar-se-ão ao Plano de Desenvolvimento Urbano Integrado (PDUI), mas com continuação de constante e paralelo exame da figura do Plano Diretor, com o qual aquele deve manter permanente ligação, sobretudo do ponto de vista legislativo-teórico, a fim de que se consiga, com maior chance de êxito e sucesso, gradativamente concretizar objetivos urbanísticos mores em regiões metropolitanas, aglomerantes de vários municípios. Objetivos que já poderão ser quiçá examinados em também já casos concretos de começo de criação ou implementação propriamente dita do Plano de Desenvolvimento Integrado (PDUI). Este o rumo da pesquisa, cujos primeiros resultados já se apresentam. E é neste caminho que se seguirá, no momento logo subsequente.

\section{VISÕES LEGISLATIVAS, EXPERIÊNCIAS CONCRETAS DO PLANO DE DESENVOLVIMENTO URBANO INTEGRADO (PDUI) E PRIMEIRAS CONCLUSÕES, CRÍTICAS E PROBLEMÁTICAS INSTITUCIONAIS}

A movimentação de regiões metropolitanas do país e a já ocorrência de criação do Plano de Desenvolvimento Urbano Integrado (PDUI) mostra, por um lado, amadurecimentos institucionais ligados à sua criação, mas, por outro, preocupação quanto à sua real possibilidade aplicacional. Pois a rapidez pode significar tanto a devida e merecida atenção que o Plano de 
Desenvolvimento Urbano Integrado (PDUI) merece, quanto uma mera demonstração de conteúdo vazio, que finde por não acolher o mais importante princípio dos planos urbanísticos ligado à relevância do Plano de Desenvolvimento Urbano Integrado (PDUI), qual seja, o acima já explorado princípio da articulação.

Sem que municípios limítrofes e que formam uma região metropolitana também firmem um diálogo, uma comunicação, que podem perfeitamente acontecer já no processo de elaboração do Plano de Desenvolvimento Urbano Integrado (PDUI), este pode tornar-se inócuo e mera propaganda político-legislativa. Vale sempre lembrar que os últimos anos, assim como os próximos, são indicativos de uma crise política sem precedentes na democracia representativa brasileira, o que leva a crer que a possibilidade de uma falta de adequado exame, com a participação institucional ativa dos municípios que integram região metropolitana na qual já foi implantado o Plano de Desenvolvimento Urbano Integrado (PDUI), seja uma realidade e não simples suposição. É certo que avanços, como a realização já mais frequente de audiências públicas, entre outros mecanismos de comunicação entre instituições e entre estas e a própria população, são dignos de louvor ${ }^{9}$. Mas para um país no qual se detecta uma dramática crise urbanística, a insuficiência e deficiência de medidas, por melhores e mais bem intencionadas que sejam, passam a ser sempre a maior preocupação.

De todo modo, se mesmo com prazo dilatado para sua realização ${ }^{10}$, há regiões metropolitanas que já deram o pontapé inicial para a existência do Plano de Desenvolvimento

\footnotetext{
9 Aproveite-se para já citar a chamada governança interfederativa. O Capítulo III do Estatuto da Metrópole é inteiramente a ela dedicado. Embora o foco deste Artigo seja o Plano de Desenvolvimento Urbano Integrado (PDUI), com seus desdobramentos enquanto plano urbanístico, tal qual o Plano Diretor, eis o inteiro teor do Art. 6으, da Lei 13.089/2015, que traz os princípios da, repita-se, chamada governança interfederativa: "Art. $6^{\circ} \mathrm{A}$ governança interfederativa das regiões metropolitanas e das aglomerações urbanas respeitará os seguintes princípios: I - prevalência do interesse comum sobre o local; II - compartilhamento de responsabilidades para a promoção do desenvolvimento urbano integrado; III - autonomia dos entes da Federação; IV - observância das peculiaridades regionais e locais; V - gestão democrática da cidade, consoante os arts. 43 a 45 da Lei n 10.257, de 10 de julho de 2001; VI - efetividade no uso dos recursos públicos; VII - busca do desenvolvimento sustentável". E, com foco maior no objeto central do presente Artigo, assim estatui Art. 10, § 4으, do Estatuto da Metrópole: "§ $4^{\circ} \mathrm{O}$ plano previsto no caput deste artigo será elaborado no âmbito da estrutura de governança interfederativa e aprovado pela instância colegiada deliberativa a que se refere o inciso II do caput do art. $8^{\circ}$ desta Lei, antes do envio à respectiva assembleia legislativa estadual".

10 O Estatuto da Metrópole seguiu o exemplo do Estatuto da Cidade ao estabelecer as normas que obrigam os Estados a elaborarem seus Planos de Desenvolvimento Urbano Integrado (PDUI). De forma mais precisa, seguiu o exemplo ao trazer os casos em que agentes públicos poderão incorrer em improbidade administrativa por omissão na tomada de providências. Este o teor do Art. 21, que findou por já ser alvo de alteração em prol da dilatação do prazo para que Estados elaborem seus Planos de Desenvolvimento Urbano Integrado (PDUI): “Art. 21. Incorre em improbidade administrativa, nos termos da Lei n 8.429, de 2 de junho de 1992: I - o governador ou agente público que atue na estrutura de
} 
Urbano Integrado (PDUI) e, com isso, para o próprio fortalecimento do Estatuto da Metrópole e de suas pretensões, no mínimo um aplauso, ainda que isolado, merece ser ouvido. Afinal de contas, uma tão recente lei ter seu principal instituto e instrumento já em concretização, é fato comprobatório de uma não cegueira política e jurídica, mesmo que puramente superficial.

Mas antes de se adentrar, assim, exemplos e experiências, é importante reservar espaço para importantes considerações críticas sobre a previsão legal do Plano de Desenvolvimento Urbano Integrado (PDUI) no próprio Estatuto da Metrópole. E, na mesma medida, ressaltar o grau da importância relacional entre Plano de Desenvolvimento Urbano Integrado (PDUI) e Planos Diretores que se encontram ou vão se encontrar sob sua égide maior, mais precisamente, os dos municípios integrantes da região metropolitana já abraçada ou a ser abarcada por um Plano de Desenvolvimento Urbano Integrado (PDUI).

O Brasil é um terreno fértil para a demonstração de malfadadas experiências legislativas, decisões judiciais e medidas executivas de vitrine, ou seja, "apenas para olhar e não para tocar, nem comprar". A analogia representa a ideia de que muitas leis não são "compradas", isto é, profícuas, seja para a população interessada, seja para todo o conjunto institucional porventura afetado. Uma espécie de inocuidade crônica, que atinge, guardadas as devidas proporções, várias medidas judiciais, sobretudo de consequências indiretas ou omissivas e, outrossim, atos executivos.

Desse modo, o que estabelece o Estatuto da Metrópole?

Para além do já examinado, quando o foco, apesar de mais inclinado a nuanças específicas e recortadas do Plano Diretor, não deixou também de atingir e se valer de previsões

governança interfederativa que deixar de tomar as providências necessárias para: a) garantir o cumprimento do disposto no caput do art. 10 no prazo de cinco anos, contado da data da instituição da região metropolitana ou da aglomeração urbana; e b) a elaboração, no âmbito da estrutura de governança interfederativa, e a aprovação pela instância colegiada deliberativa, até 31 de dezembro de 2021, do plano de desenvolvimento urbano integrado das regiões metropolitanas ou das aglomerações urbanas". Repita-se e se repare que a redação de 2015, original do Estatuto da Metrópole, já foi alterada (por meio de redação dada pela Medida Provisória no 818, de 2018, a qual mudou, por exemplo, os 03 anos contidos na redação original das alínea "a" e "b", do inciso I, do Art. 21, para 05 anos e para a data de 31 de dezembro de 2021, respectivamente), estendendo-se o prazo para que os Estados membros da Federação brasileira e seus agentes públicos, tomem as providências necessárias para a elaboração do Plano de Desenvolvimento Urbano Integrado (PDUI). Os ora Autores, da mesma maneira em que criticam a redação do Estatuto da Cidade quando da utilização da oração "deixar de tomar as providencias necessárias" (Art. 52 e seus incisos, da Lei 10.257/2001), tecem igual crítica ao Estatuto da Metrópole, lei, praticamente, 15 anos mais nova que o Estatuto da Cidade, mas não capaz de criar mecanismos mais efetivos de vinculação da Administração Pública para a criação dos respectivos Planos de Desenvolvimento Urbano Integrado (PDUI) nas regiões metropolitanas brasileiras. 
estatutárias da Lei 13.089, de 12 de janeiro de 2015, há relevantes questões a serem ainda enfrentadas, de modo a se respeitar, com rigor, os fitos colimados no presente Artigo.

E a primeira já decorre do próprio Art. 1ㅇ do Estatuto da Metrópole, que declara que serão no documento legislativo por aquele inaugurado, trazidas normas gerais sobre o Plano de Desenvolvimento Urbano Integrado (PDUI) ${ }^{11}$. E aqui se entende que sempre que uma legislação de vanguarda em matéria urbanística promete trazer normas gerais a respeito de determinado instituto, deve-se comemorar por um lado e, na mesma medida, preocupar-se por outro.

Em se tratando, em uma possível linha de análise, de comemoração, a ideia é aquela clássica, segundo a qual se um novo e relevante instituto é legislativamente criado, agiu de forma adequada o parlamentar, fazendo aquilo que dele se espera: criar normas jurídicas necessitadas (no sentido mais amplo do vocábulo) pelo país. Mas, ressalte-se, quando se está diante de instituto de Direito Urbanístico, algumas outras questões exsurgem, a principal das quais, talvez, ligada à estrutura federal brasileira e à relação imediata entre criação do instituto e sua aplicabilidade, efetividade e validade ${ }^{12}$. Pois é preciso, em matéria urbanística, vestibularmente respeitar a lógica de divisão de competências construída pelo legislador constituinte originário e reforçada por teorias e experiências durante os aproximados 30 (trinta) anos da Constituição de 1988, de maneira a fazer com que, preponderantemente, matérias

\footnotetext{
11 "Art. 1ํ. Esta Lei, denominada Estatuto da Metrópole, estabelece diretrizes gerais para o planejamento, a gestão e a execução das funções públicas de interesse comum em regiões metropolitanas e em aglomerações urbanas instituídas pelos Estados, normas gerais sobre o plano de desenvolvimento urbano integrado e outros instrumentos de governança interfederativa, e critérios para o apoio da União a ações que envolvam governança interfederativa no campo do desenvolvimento urbano, com base nos incisos XX do art. 21, IX do art. 23 e I do art. 24, no § 30 do art. 25 e no art. 182 da Constituição Federal".

${ }^{12}$ Conforme bem anuncia Luigi Ferrajoli, há diferença marcante entre vigência e validade. Nos termos do por ele definido, a vigência de uma norma mais se aproximaria da ideia de norma regularmente elaborada. Em palavras mais precisas, norma vigente é aquela criada e formada em respeito incondicional ao devido processo legal processual. Seguindo o legislador rigorosamente as regras impostas para a elaboração das variadas espécies normativas, a lei resultante de tal trabalho será necessariamente vigente, ou seja, vigorará no Ordenamento Jurídico brasileiro. Já validade mais se aproximaria da ideia de substancialidade da norma, diferença melhor explicada nas palavras do próprio autor citado: "Se trata, pues, de dos conceptos asimétricos e independientes entre sí: la vigencia guarda con la forma de los actos normativos, es una cuestión de subsunción o de correspondencia de las formas de los actos productivos de normas con las previstas por las normas formales sobre su formación; la validez, al referirse al significado, es por el contrario una cuestión de coherencia o compatibilidad de las normas producidas con las de carácter sustancial sobre su producción" (FERRAJOLI, 2002, p. 21-22). Do mesmo autor, entre vários estudos, conferir o trabalho intitulado "Principia iuris. Teoria Del diritto e della democrazia" (FERRAJOLI, 2007). A ideia de validade aqui apresentada muito se aproxima da noção de efetividade, trabalhada por diversos autores, dentre eles Luís Roberto Barroso, segundo o qual: "A efetividade significa, portanto, a realização do Direito, o desempenho concreto de sua função social. Ela representa a materialização, no mundo dos fatos, dos preceitos legais e simboliza a aproximação, tão íntima quanto possível, entre o dever-ser normativo e o ser da realidade social" (BARROSO, 2000, p. 85).
} 
urbanísticas sejam tratadas pelos municípios, legisladores mores de assuntos sobre interesses locais (Art. 30, inciso I, da Constituição da República).

Portanto, quando o Estatuto da Metrópole cria o Plano de Desenvolvimento Urbano Integrado (PDUI) e o coloca em posição hierárquica superior aos Planos Diretores, já é importante saber se usurpa competência municipal ou não, uma vez que seus objetivos são eminentemente urbanísticos. Conforme já se pôde verificar no subtítulo anterior, não parece o Plano de Desenvolvimento Urbano Integrado (PDUI) teórica e legislativamente conflitar com os Planos Diretores e tampouco com a dinâmica constitucional de subdivisão de competências em matéria urbanística. No que tange ao Planos Diretores, o mencionado princípio da hierarquia, que deve reger a relação entre planos urbanísticos, faz com que o surgimento de um plano hierarquicamente superior ou inferior a qualquer outro preexistente não gere problemas de ordem jurídica, salvo se houver desvios indevidos de condução do instituto. Concomitantemente, no que diz respeito à dinâmica constitucional de repartição de competências, uma lei federal, respeitando o princípio da tipicidade dos planos urbanísticos, ao criar um novo plano - no caso, o Plano de Desenvolvimento Urbano Integrado (PDUI) - e logo salientar que apenas trará normas gerais sobre o mesmo, mostra-se deferente aos comandos constitucionais sobre o tema.

Mas é preciso descer mais um degrau, de modo a se aprofundar ainda um pouco mais. Se a lei e, mais precisamente, o Estatuto da Metrópole, traz normas gerais sobre Plano de Desenvolvimento Urbano Integrado (PDUI), da mesma forma, por exemplo, que o Estatuto da Cidade, Lei 10.257/2001, é portador de normas gerais sobre o Plano Diretor, é fundamental perceber, estudar, perquirir e perscrutar, em uma atividade constante, qual o grau de generalidade escolhido pelo legislador. E isto porque, a própria experiência com os Planos Diretores mostrou que, em certos momentos, a generalidade e o nível de liberdade dados aos municípios para a criação de seus Planos Diretores foram muito benéficas e constitucionais. Contudo, em algumas situações, esta mesma generalidade já se mostrou um problema, sobretudo quando em assuntos mais sensíveis algumas liberdades transformaram-se em arbitrariedades municipais no processo de criação de seus Planos Diretores, fato, em muitos casos, maléfico aos municípios e, por conseguinte, cidades abrangidas por determinado Plano Diretor. Exemplos rápidos e objetivos, mas suficientes, são sempre os ligados ao tamanho e à intensidade de pressões políticas e econômicas que Câmaras dos Vereadores podem potencial e verdadeiramente sofrer de grupos sociais e seus interesses, no âmbito municipal. Pressões estas que poderiam ser mais reduzidas e diluídas em esferas federativas maiores e mais amplas. 
Por outro lado, uma também outra e fundamental preocupação vem naturalmente à tona quando uma lei como o Estatuto da Metrópole, além de logo em seu primeiro dispositivo estabelecer que será a lei portadora de normas gerais sobre o Plano de Desenvolvimento Urbano Integrado (PDUI), igualmente ser a criadora do referido plano, tipificando-o pela primeira vez no ordenamento jurídico.

Ora, ao criar a tipificação em um Estado como o brasileiro e, logicamente, trazer características, requisitos e condições para o instituto, finda por ter que observar a estrutura constitucional existente. Mais uma vez se menciona a necessidade de observância dos preceitos constitucionais vigentes, mas com foco redirecionado. Assim, em razão de o Estatuto em comento cuidar da figura das metrópoles, aglomerações urbanas compostas por mais de um município, é praticamente inevitável conferir ao grau federativo imediatamente superior ao municipal a competência para a criação do Plano de Desenvolvimento Urbano Integrado (PDUI), o qual, frise-se, deve obediência total ao Estatuto da Metrópole e à Constituição da República. Ocorre que, ao se fazer isso em uma estrutura como a nacional, deve-se e se deverá ter um cuidado redobrado para que as características e competências de cada plano urbanístico sejam respeitadas ${ }^{13}$.

Especificamente, quer-se dizer que, nada obstante desde o início se entender como muito salutar e positiva a chegada e já início de implantação de Planos de Desenvolvimento Urbano Integrado (PDUI), deve-se atentar para os por vezes já citados princípios norteadores dos planos urbanísticos (a lembrar: hierarquia, tipicidade e articulação), a fim de que os desdobramentos axiológicos cumpram a função estabilizadora, conformadora e balizadora do sistema de normas jurídicas e, no caso, urbanísticas, com a finalidade de otimizar e aproveitar, na maior grandeza possível, o potencial de institutos como os planos urbanísticos aqui tratados. De competência dos Estados-membros da Federação brasileira, é imprescindível que o viés de um Plano de Desenvolvimento Urbano Integrado (PDUI) seja o de estabelecimento de normas, cujo olhar de seus criadores tenha sido mais amplo se comparado ao olhar do criador de um Plano Diretor. E que este olhar atente para a maior amplitude da metrópole se também comparada ao município, assim como, na mesma medida, atente para não ultrapassar

\footnotetext{
${ }^{13}$ Que se registre que o legislador criador do Estatuto da Metrópole preocupou-se em diferenciar o Plano de Desenvolvimento Urbano Integrado (PDUI) do Plano Diretor. Confira-se, novamente a previsão estatutária, uma vez que já anteriormente mencionada neste Artigo, mas para fins diferenciados: "Art. 10. (...) $\S 2^{\circ} \mathrm{A}$ elaboração do plano previsto no caput deste artigo não exime o Município integrante da região metropolitana ou aglomeração urbana da formulação do respectivo plano diretor, nos termos do $\S$ $1^{\circ}$ do art. 182 da Constituição Federal e da Lei no 10.257, de 10 de julho de 2001".
} 
fronteiras de atuação, tanto para além das bordas de uma Metrópole, quanto para o interior de competências estritamente municipais ${ }^{14}$.

Em sequência, considerando a já citação ao Estatuto da Cidade, é também relevante aqui mencionar a relação estabelecida pelo legislador entre aquela legislação e o Estatuto da Metrópole. E, logo no § 2oㅡ, do Art. 1ํ, deixou-se claro que na aplicação das disposições da Lei 13.089/2015, serão observadas as normas gerais de Direito Urbanístico estabelecidas na Lei 10.257/2001 (Estatuto da Cidade), assim como as estabelecidas em outras leis federais que, de alguma maneira, já versam sobre temas e trazem normas igualmente gerais sobre saneamento básico, mobilidade urbana, meio ambiente, habitação e políticas nacionais de desenvolvimento urbano e de desenvolvimento regional ${ }^{15}$. Na mesma linha, reforce-se a relação do Plano de Desenvolvimento Urbano Integrado (PDUI) com o Estatuto da Cidade, sobretudo na figura do Plano Diretor, com normas gerais presentes no apenas citado Estatuto e decorrentes do mandamento constitucional complementador, já atendido pelo legislador infraconstitucional brasileiro, no que tange, sobretudo, mas não somente, ao contido no Art. 182 da Constituição da República ${ }^{16}$

Nesse contexto, não apenas foram utilizados expedientes legislativos de citação a artigos do Estatuto da Cidade, por exemplo, mas também foram inseridas na parte do Estatuto da Metrópole destinada à regulação do Plano de Desenvolvimento Urbano Integrado (PDUI),

\footnotetext{
${ }^{14}$ É claro que esta é uma avaliação de grande nível de complexidade, sobretudo prática, porque, muitas vezes, será aconselhável, útil e aceitável que um Plano de Desenvolvimento Urbano Integrado (PDUI) escape algumas fronteiras metropolitanas, com naturais previsões futurísticas de expansão de um território. E, da mesma forma, também recomendável que adentre certas particularidades municipais para poder promover, por exemplo o tão desejado e pelos autores festejado atendimento ao princípio da articulação, de magnitude ímpar em um cenário de tão gigantescas aglomerações urbanas e, por consequência, de necessidades comuns de vários municípios contíguos, mas carentes de planejamento urbano e ordenação territorial uniforme, em razão, principalmente, da até então inexistência de plano urbanístico de maior abrangência e hierarquia que o Plano Diretor, normalmente restrito aos interesses exclusivamente municipais e dos respetivos e exatos territórios. E fartos são exemplos, de acordo com o já neste trabalho afirmado, que demonstram que regiões metropolitanas possuem intensa dinâmica articulada. Transportes públicos e individuais, vias de circulação, oferta e demanda de postos de trabalho, relação moradia-emprego (casa-trabalho), entre tantas ilustrações, confirmam o que ora se corrobora.

15 “Art. 1‥ (...) § $2^{\circ} \mathrm{Na}$ aplicação das disposições desta Lei, serão observadas as normas gerais de direito urbanístico estabelecidas na Lei $n^{\circ}$ 10.257, de 10 de julho de 2001 - Estatuto da Cidade, que regulamenta os arts. 182 e 183 da Constituição Federal, estabelece diretrizes gerais da política urbana e dá outras providências, e em outras leis federais, bem como as regras que disciplinam a política nacional de desenvolvimento urbano, a política nacional de desenvolvimento regional e as políticas setoriais de habitação, saneamento básico, mobilidade urbana e meio ambiente".

${ }^{16}$ Vale lembrar que o Art. 10, § 3으, do Estatuto da Metrópole fixa a relação de hierarquia entre o Plano de Desenvolvimento Urbano Integrado (PDUI) e o Plano Diretor (aquele hierarquicamente superior a este, logicamente, conforme já exposto, naquilo que couber e estiver em conformidade com as finalidades e abrangência de cada plano).
} 
normas semelhantes às contidas no Estatuto da Cidade para a normatização básica e geral da figura e instituto do Plano Diretor. Assim, no tocante à revisão decenal, veja-se o teor do Art. 11 do Estatuto da Metrópole: "A lei estadual que instituir o plano de desenvolvimento urbano integrado de região metropolitana ou de aglomeração urbana deverá ser revista, pelo menos, a cada 10 (dez) anos".

No mesmo rumo, os elogios - sem a presença, paralelamente, de necessárias e proveitosas críticas oriundas de vários grupos e setores sociais, que ora, por opção dos Autores e respeito ao recorte temático, não serão detalhadas, nem, muito menos elencadas e enumeradas - ao Estatuto da Cidade no tocante à participação popular no processo de elaboração do Plano Diretor, renderam frutos para o Plano de Desenvolvimento Urbano Integrado (PDUI), com o reforço da participação institucional do Ministério Público. O Art. 12, § 2o, com redação também já modificada, assim determina:

Art. 12. O plano de desenvolvimento urbano integrado de região metropolitana ou de aglomeração urbana deverá considerar o conjunto de Municípios que compõem a unidade territorial urbana e abranger áreas urbanas e rurais.

(...)

$\S 2^{\circ}$ No processo de elaboração do plano previsto no caput deste artigo e na fiscalização de sua aplicação, serão assegurados:

I - a promoção de audiências públicas com a participação de representantes da sociedade civil e da população;

II - a publicidade quanto aos documentos e informações produzidos; e

III - o acompanhamento pelo Ministério Público. ${ }^{17}$

E, como se citou modificação no dispositivo, que se cite a redação anterior do inciso I, do $\S 2$ 을 do Art. 12, objeto da referida alteração: "I - a promoção de audiências públicas e debates com a participação de representantes da sociedade civil e da população, em todos os Municípios integrantes da unidade territorial urbana". O entendimento que se profere é de patente retrocesso, pois a palavra "debates" foi retirada, assim como a parte final, na qual se fazia expressa menção à necessidade de oitiva a todos os municípios integrantes da região metropolitana. Ora, quanto ao vocábulo "debates", pode-se até argumentar, hipoteticamente, que seria redundante, em razão de existir interpretação que defenda que a participação de representantes da sociedade civil e da população inclui a noção de debates, muito embora

\footnotetext{
${ }^{17}$ Vale a pena conferir comparação com semelhante Artigo do Estatuto da Cidade: "§ $4^{\circ}$ No processo de elaboração do plano diretor e na fiscalização de sua implementação, os Poderes Legislativo e Executivo municipais garantirão: I - a promoção de audiências públicas e debates com a participação da população e de associações representativas dos vários segmentos da comunidade; II - a publicidade quanto aos documentos e informações produzidos; III - o acesso de qualquer interessado aos documentos e informações produzidos".
} 
possa se argumentar a existência de manifesta distinção entre os preceitos e, portanto, discordar da alteração normativa. Mas, no que diz respeito à oitiva de todos os municípios de uma região metropolitana, peca, clamorosamente, a mudança legal, pois o Plano de Desenvolvimento Urbano Integrado (PDUI) tem como um de seus centrais objetivos a integração de toda uma aglomeração urbana, composta pela integralidade dos municípios que a compõem.

Para além de outras previsões legais que não necessitam ser aqui examinadas, porque classificadas como redundantes, pode-se finalmente partir para um exame concreto da situação atual dos Estados brasileiros, no que tange à criação do Plano de Desenvolvimento Urbano Integrado (PDUI), principalmente se levado em conta o prazo inicial de 03 (três) anos, antes previsto no Art. 21, inciso I, alíneas "a" e "b", da Lei 13.089, de 12 de janeiro 2015. Esta é uma das razões da pesquisa, cujos resultados ora se apresentam. Não houvessem sido tais dispositivos alterados, a obrigação de elaboração do Plano de Desenvolvimento Urbano Integrado (PDUI) por cada Estado possuidor de regiões metropolitanas já teria tido seu prazo esgotado.

Então, qual o contexto geral nos possíveis abertos e encaminhados processos de elaboração do Plano de Desenvolvimento Urbano Integrado (PDUI)? Qual o retrato atual, após os 03 (três) anos inicialmente previstos do Estatuto da Metrópole, do Brasil e de suas regiões metropolitanas em matéria de criação do Plano de Desenvolvimento Urbano Integrado (PDUI)?

Preliminarmente, far-se-á breve menção, com total respeito aos objetivos bem definidos deste Artigo, aos alicerces teóricos, em seara jurídica e constitucional, das chamadas regiões metropolitanas, pois são exatamente para elas que devem ser criados os Planos de Desenvolvimento Urbano Integrado (PDUI), pelos respectivos e correspondentes Estados membros da Federação brasileira. Por conseguinte e, sem delongas, assim estatui o Art. 25, § 3o, da Constituição de 1988:

Art. 25. Os Estados organizam-se e regem-se pelas Constituições e leis que adotarem, observados os princípios desta Constituição.

(...)

$\S 3$ ○ Os Estados poderão, mediante lei complementar, instituir regiões metropolitanas, aglomerações urbanas e microrregiões, constituídas por agrupamentos de municípios limítrofes, para integrar a organização, o planejamento e a execução de funções públicas de interesse comum.

Nesse sentido, é de competência dos Estados, além da criação do(s) Plano(s) de Desenvolvimento Urbano Integrado (PDUI) para cada região metropolitana (lembrando que o número de regiões metropolitanas variará dentro de cada um dos 26 Estados brasileiros), 
também, por meio de lei complementar estadual, criar regiões metropolitanas. E isso conduz a um ponto para o qual se chama especial atenção, desde logo: embora as variações tendam a ser poucas, números a seguir informados podem sofrer alterações, ainda que pequenas, caso sejam criadas novas regiões metropolitanas após a conclusão do presente Artigo. Nada, na opinião de quem aqui escreve, que comprometa os resultados finais da pesquisa ora proposta, mas informação a ser logo destacada.

Com a chegada do Estatuto da Metrópole (Lei 13.089, de 12 de janeiro de 2015), as regiões metropolitanas ganharam um novo fôlego e o Plano de Desenvolvimento Urbano Integrado (PDUI), certamente, é entendido como uma das principais, senão a maior causa desse novo fôlego e, por corolário, relevância jurídica, social, econômica, política e, por que não dizer, dentro da esfera jurídica, nova e revigorada relevância urbanística. Que, então, já se informe: 69 (sessenta e nove) são as regiões metropolitanas hoje formal e legalmente existentes no Brasil, de acordo com dados oficiais ${ }^{18}$. Uma média de 2,65 (duas vírgula sessenta e cinco) ${ }^{19}$ por Estado, embora a maioria se concentre no Estado da Paraíba, o qual possui 11 (onze) regiões metropolitanas, seguido pelos Estados de Santa Catarina com 09 (nove) - apesar de o número fornecido pelo sítio eletrônico do Governo do Estado de Santa Catarina apontar para onze regiões metropolitanas, duas a mais que o número apontado pelo Instituto Brasileiro de Geografia e Estatística (IBGE) 20 -, Alagoas e Paraná com 08 (oito) ${ }^{21}$, São Paulo com 06 (seis), e Roraima e Ceará com 03 (três) regiões metropolitanas cada.

\footnotetext{
${ }^{18}$ Os dados são do Instituto Brasileiro de Geografia e Estatística (IBGE), cuja página no sítio eletrônico teve última atualização em 010 de fevereiro de 2018 (SOUZA, 2018). Apesar da indicação oficial de 69 (sessenta e nove) regiões metropolitanas, a tendência é de variações neste número, ou para aumento, tendo em vista não somente o natural crescimento de cidades e áreas urbanas, mas também a chegada do Estatuto da Metrópole e da condição de existência de uma região metropolitana para que se crie o Plano de Desenvolvimento Urbano Integrado (PDUI), plano urbanístico que pode ser de interesse de muitos Estados para apoio de seu desenvolvimento urbano e ordenação territorial, ou para diminuição, em casos de um caminho aproximadamente oposto ao apenas narrado, sobretudo de não consolidação fática, social e econômica de uma determinada aglomeração urbana.

${ }^{19}$ Caso se compute o Distrito Federal, a média será de 2,55 (duas vírgula cinquenta e cinco).

20 Informações disponíveis em: <https://www.ibge.gov.br>, com última atualização em 11 de março de 2018. Já no sítio eletrônico do Governo do Estado de Santa Catarina, assim resta explanado: "O Estado de Santa Catarina, conforme as Leis Complementares n 475/2010, 523/2010 e 571/2012, é formado por 11 Regiões Metropolitanas. São elas: regiões metropolitanas de Florianópolis, do Vale do Itajaí, do Alto Vale do Itajaí, do Norte/Nordeste Catarinense, de Lages, da Foz do Rio Itajaí, Carbonífera, de Tubarão, de Chapecó, do Extremo Oeste e do Contestado" (SECRETARIA DE ESTADO DO PLANEJAMENTO, 2018).

${ }^{21}$ Apesar de o Estado do Paraná poder ter de uma a três regiões metropolitanas extintas, se aprovadas leis estaduais neste sentido. Tratam-se das regiões de Umuarama, assim como as de Apucarana, Campo Mourão e Toledo (REGIÃO METROPOLITANA DE UMUARAMA E OUTRAS TRÊS DEVEM SER EXTINTAS, 2017). Reforce-se, entretanto, que quantidade de regiões metropolitanas não se confunde com sua
} 
Se este é um breve retrato da existência e distribuição das regiões metropolitanas do Brasil, exposição apenas anunciativa e portadora de elementos exordiais para um exame nacional da situação, patamar e nível de andamento da criação do Plano de Desenvolvimento Urbano Integrado (PDUI) país afora, não deixa, paralelamente, de trazer dados bastante relevantes, sobretudo a partir dos números e estatísticas apresentados. De todo modo, ressalte-se, são dados trazidos para que se chegue a um objetivo mor e específico, tendo em vista as próprias e, desde o início expostas, finalidades do presente Artigo.

Nesse viés e, com foco agora diretamente direcionado ao quadro brasileiro situacional do Plano de Desenvolvimento Urbano Integrado (PDUI), após os 03 (três) anos da chegada do Estatuto da Metrópole e do prazo inicialmente estipulado para sua implantação pelos Estados detentores de regiões metropolitanas, o ora estudo prossegue para conclusões e resultados. E o primeiro deles é o de que, se considerada a existência de praticamente 07 (sete) dezenas de regiões metropolitanas no Brasil, a maioria absoluta não conseguiu elaborar o referido Plano. Caso se pense em "tomada de providências", como expressado em lei e com específicas críticas anteriormente colocadas, o número de Estados que se movimentou para a criação de seus Planos de Desenvolvimento Urbano Integrado (PDUI) aumenta, mas pode ser ainda considerado baixo dentro do grande universo de regiões metropolitanas no país. Apenas 01 (um) Estado efetivamente criou, dentro dos 03 (três) primeiros anos de vigência da Lei 13.089/2015 e do prazo até o início de 2018 previsto na própria lei para a criação dos respectivos Planos, o seu Plano de Desenvolvimento Urbano Integrado (PDUI). Trata-se do Estado do Espírito Santo, o qual, pela Lei Complementar no 872, de 07 de dezembro de 2017, instituiu o Plano de Desenvolvimento Urbano Integrado (PDUI) da Região Metropolitana da Grande Vitória (RMGV). Independentemente de qualquer análise qualitativa da citada criação pela Região Metropolitana da Grande Vitória (RMGV), absolutamente pioneira no país para o que aqui se perscruta, é digno de elogios o grau de diligência do Estado do Espírito Santo e da mencionada Região Metropolitana no cumprimento de disposição contida em lei federal e, mais do que isso, de demonstração da importância dada à figura dos planos urbanísticos, em especial do novo plano trazido pelo Estatuto da Metrópole. Enquanto tantos Estados e regiões metropolitanas sequer se movimentaram e algumas e alguns outros, embora "tomando providências", não conseguiram concluir o processo de elaboração, que finda com a aprovação da lei instituidora

população. Assim, Estados com maior número de regiões metropolitanas não necessariamente terão as mais populosas regiões metropolitanas do país. 
do Plano de Desenvolvimento Urbano Integrado (PDUI), o Poder Legislativo do Estado do Espírito Santo, por meio de sua Assembleia Legislativa, foi capaz de fazê-lo.

Contudo, para além do caso apenas apresentado, vale mencionar outros Estados em que se pôde averiguar e observar movimentações, apesar de não concluídas, em prol da criação do Plano de Desenvolvimento Urbano Integrado (PDUI). E aqui haverá uma seletividade, a partir da anunciação apenas dos casos reputados mais emblemáticos, avançados e/ou relevantes do ponto de vista dos pesquisadores. Escolhas necessárias, mas muito bem alicerçadas nas bases de dados e informativos sobre as quais se funda o presente Artigo e com base, portanto, nos resultados da ampla pesquisa realizada.

Assim, em uma subdivisão neste Artigo livremente ${ }^{22}$ escolhida como em 04 (quatro) estágios, denominados (a) inicial, (b) em andamento, (c) avançado e (d) finalizado, Regiões Metropolitanas como as de Macapá (AP), Manaus (AM), Belém (PA), Santarém (PA) e Sorocaba (SP), iniciaram os trabalhos ("estágio inicial"), ao passo que nas Regiões Metropolitanas de Cariri (CE), Fortaleza (CE), Sobral (CE), Recife (PE), Aracaju (SE), Campinas (SP), São Paulo (SP), Belo Horizonte (MG), Cascavel (PR), Londrina (PR), Maringá (PR), Curitiba (PR) e Florianópolis (SC), observou-se um estágio já além do inicial, com variações de acordo com cada região metropolitana ("estágio em andamento"). Salientem-se, ainda, as regiões metropolitanas nas quais se percebeu um momento mais avançado em comparação com o anterior e mais próximo (com naturais oscilações caso a caso) a etapas conclusivas ("estágio avançado"), fato observado nas Regiões de Salvador (BA), Goiânia (GO), Vale do Rio Cuiabá (MT), Rio de Janeiro (RJ), Baixada Santista (SP), Vale do Aço (MG) e Porto Alegre (RS). E, por fim, em conformidade com o já acima exposto, no último estágio ("estágio finalizado"), apenas a Região Metropolitana da Grande Vitória (ES), na qual o Plano de Desenvolvimento Urbano Integrado (PDUI) se encontra pronto, acabado e em vigor ${ }^{23}$.

\footnotetext{
22 Livremente, mas a partir de uma comparação entre o grau de andamento dos Processos nas regiões metropolitanas e Estados onde se pôde observar movimentações em prol da criação do Plano de Desenvolvimento Urbano Integrado (PDUI). Tal comparação, desse modo, sobretudo a partir de pesquisas em sítios eletrônicos de entes públicos e privados variados, proporcionou a criação de estágios como o (a) inicial, o (b) em andamento, o (c) avançado e o (d) finalizado. Mais precisamente, (a) o de um já mero início de atividades no sentido de criação do Plano de Desenvolvimento Urbano Integrado (PDUI); o de (b) um maior encaminhamento do processo, com, em alguns casos, marcações de audiências públicas ou já realizações das mesmas; um ainda terceiro estágio, (c) em que primeiras ou mais adiantadas minutas já se apresentavam e condições de serem submetidas em Plenário de Assembleias Legislativas; e, por fim, um último estágio, (d) no qual o Plano de Desenvolvimento Urbano Integrado (PDUI) já havia sido legislativamente aprovado, com sua instituição já ocorrida por meio de lei estadual.

${ }^{23} \mathrm{O}$ presente Artigo conta com 01 (um) ANEXO, composto por 04 (quatro) Tabelas, no qual, a fim de não se inflar o texto principal com dezenas de citações de sítios eletrônicos, poder-se-á observar as principais
} 
É importante frisar que cada Estado brasileiro segue ritos estaduais próprios (apesar de necessariamente semelhantes), dada a própria autonomia estadual federativa, desde que respeitosos à legislação nacional a eles direcionada e à Constituição da República. Entretanto, relativamente a tais ritos, ainda que críticas possam ser desferidas quanto ao grau de participação popular no processo, nos Estados e regiões metropolitanas onde os processos já abriram espaço para tal, audiências públicas já realizadas ou a se realizarem, mostram-se presentes no processo de criação do Plano de Desenvolvimento Urbano Integrado (PDUI). E a menção a críticas diz respeito, sobretudo, a um problema que não se restringe aos planos urbanísticos, que, aliás, são um exemplo de legislação em cujo processo de elaboração a simples representatividade eleitoral não é suficiente. Elogios ao Plano Diretor, ao Plano de Desenvolvimento Urbano Integrado (PDUI), mas críticas ao fato de meios de participação popular mais variados e modernos não terem ainda ganhado força no país. E também a crítica já direcionada à modificação do Estatuto da Metrópole, a qual retirou a palavra "debates" do texto do Art. 12, § 2ำ, inciso I, com marcante intenção de não deixar margens para ampliações de participação da população brasileira. Que, repita-se, finda por ter restrita sua participação em processos nos quais Ihe é permitida a manifestação, até mesmo pelas próprias barreiras informacionais, de divulgação e de organização social ${ }^{24}$. O uso da tecnologia pode ainda muito fortificar um avanço na matéria, desde que conduzido de modo responsável, ético, profissional e competente, como devem ser as tarefas exercidas pela Administração Pública em todos os seus setores.

$\mathrm{Na}$ linha, por conseguinte, do até aqui visto, entende-se pertinente fazer-se alguns comentários pontuais e específicos ao único Plano de Desenvolvimento Urbano Integrado (PDUI) hoje (nunca é demais repetir, após os três anos inicialmente previstos no Estatuto da Metrópole, marco temporal também utilizado para o começo, desenvolvimento e conclusão da

fontes das quais os Autores extraíram a classificação nos estágios mencionados, assim como eventuais observações entendidas pertinentes pelos ora pesquisadores.

${ }^{24}$ Basta perceber que, em variados processos e procedimentos - não somente legislativos -, em que se permite a participação popular, normalmente associações ou grupos sociais organizados é que se fazem presentes. É certo que, em uma sociedade com mais de duas centenas de milhões de pessoas, não é tarefa fácil organizar uma participação eficaz e efetiva. Mas, por outro lado, a minoria absoluta das pessoas acaba por não se envolver em determinados processos e procedimentos oficiais e públicos, ora por desconhecimento, ora por dificuldades ligadas ao próprio acesso ao Poder Público, como, por exemplo, audiências públicas em locais distantes e em horários menos acessíveis etc. Saindo até da esfera legislativa e se adentrando a judicial, as próprias possibilidades de participação de terceiros em processos judiciais no Supremo Tribunal Federal, finda por ser naturalmente limitador e seletivo. Pois a própria barreira da distância para núcleos urbanos, sociais e econômicos é já um obstáculo que muitos interessados em julgamentos e leading cases não conseguem transpor. 
presente pesquisa, cujos resultados ora se coletivizam) já existente no Brasil. Serão comentários e observações breves, levando em conta, preferencialmente, o texto como um todo e, apenas quando e se necessárias, algumas menções específicas, no intuito de não serem desviados os objetivos centrais do presente Artigo.

Nesse sentido, foi por meio da Lei Complementar Estadual no 872, de 07 de dezembro de 2017, que se instituiu o Plano de Desenvolvimento Urbano Integrado (PDUI) da Região Metropolitana da Grande Vitória (RMGV). Trata-se de uma legislação com 26 (vinte e seis) artigos e 04 (quatro) anexos. Claro que outros tantos Planos de Desenvolvimento Urbano Integrado (PDUI) virão e, com eles, problemas e virtudes, assim como ocorrido com o Plano de Desenvolvimento Urbano Integrado (PDUI) ora sob análise.

De todo modo, focando em alguns pontos sobre os quais o presente Artigo se debruçou, em alguma medida, durante as linhas antecedentes, interessante mencionar, em específico, 02 (dois) dispositivos do referido Plano. O primeiro deles, logo inicial e que versa sobre o que estabelece e, por conseguinte, sobre algumas já diretrizes gerais do Plano de Desenvolvimento Urbano Integrado (PDUI) da Região Metropolitana da Grande Vitória. Eis o Art. 2ㅇ:

Art. 2o O PDUI é um instrumento de planejamento para o desenvolvimento urbano sustentável da RMGV e estabelece:

I - as diretrizes para as Funções Públicas de Interesse Comum - FPIC da RMGV, incluindo projetos estratégicos e ações prioritárias;

II - o macrozoneamento da unidade territorial da RMGV;

III - as diretrizes quanto à articulação dos municípios no parcelamento, uso e ocupação do solo urbano nas zonas de interesse metropolitano;

IV - as diretrizes quanto à articulação intersetorial das políticas públicas afetas à unidade territorial urbana da RMGV;

V - a delimitação das áreas com restrições à urbanização visando à proteção do patrimônio ambiental ou cultural, bem como das áreas sujeitas a controle especial pelo risco de desastres naturais;

$\mathrm{VI}$ - o sistema de acompanhamento e controle de suas disposições, em consonância com a governança da RMGV, estabelecida no ordenamento jurídico estadual.

Com efeito, percebam-se alguns elementos e vocábulos portadores de conteúdo rico e especial magnitude. Em primeiro lugar, cita-se a expressão "Funções Públicas de Interesse Comum", com foco na parte final da expressão, isto é, em "Interesse Comum". Um plano urbanístico mais amplo, com olhar regionalizado, deve, realmente, ter como um de seus focos maiores a atenção e a preocupação com elementos que aqui e pelos Autores se intitulam de "interseção urbanística". Por uma região metropolitana ser um espaço maior quando comprada ao município, contendo vários destes últimos dentro de seu território e, ao mesmo tempo, por 
já existir no Brasil um plano urbanístico de abrangência menor, ligado ao âmbito territorial e de atuação de cada município, o Plano de Desenvolvimento Urbano Integrado (PDUI) pode e deve voltar-se para, por exemplo, o que o legislador estadual capixaba desde o início salientou, repita-se, as "Funções Públicas de Interesse Comum". Com realce para as ideias de maior abrangência (percebida também quando do uso da palavra "macrozoneamento" no inciso II, do mesmo Art. $2^{\circ}$ ) e de hierarquia entre planos urbanísticos.

Ao mesmo tempo e, de forma coligada com o abordado no parágrafo anterior, se continuada a avaliação do mesmo Art. 2ํㅡ, em dois outros incisos há citação ao vocábulo "articulação". Como por várias vezes neste texto exposto, o princípio da articulação deve nortear a elaboração e o funcionamento de planos urbanísticos. No caso em tela, as expressões "articulação dos municípios" do inciso II e "articulação intersetorial das políticas públicas" da Região Metropolitana da Grande Vitória (RMGV) do inciso III, claramente denotam esta tão relevante necessidade, a qual finda somente por ter sua promoção estimulada quando da existência de mais de um tipo de plano urbanístico, de círculos de abrangência concêntricos e com relação de hierarquia. Portanto, o Plano de Desenvolvimento Urbano Integrado (PDUI), hierarquicamente superior aos Planos Diretores dos municípios integrantes da região metropolitana abrangida pelo primeiro plano mencionado, é um potencial organizador territorial, com "visão" mais ampla e abrangente, assim como um fomentador da articulação entre os municípios e seus respectivos planos urbanísticos de menor abrangência, que estiverem dentro de seu raio de alcance normativo.

Cumprindo os fitos e recortes temáticos deste estudo, outro ponto a ser finalmente destacado é o referente aos "eixos estratégicos", os quais apontam para matérias e assuntos de interesse notadamente comuns de toda a Região Metropolitana da Grande Vitória (RMGV). Assim estabelece o Art. 4으 do Plano ora em destaque:

Art. 4으 O PDUI é composto por diretrizes estratégicas e políticas públicas agrupadas em quatro eixos integradores:

I - Eixo Ordenamento Territorial: visa reduzir as desigualdades no acesso à infraestrutura metropolitana, integrando a ocupação do território às políticas econômica, ambiental e de mobilidade;

II - Eixo Mobilidade Urbana: visa ao planejamento e à execução de maneira articulada e integrada de intervenções que facilitem o fluxo de pessoas e de produtos e mercadorias, de tal forma a garantir a qualidade de vida e a competitividade econômica da metrópole;

III - Eixo Desenvolvimento Econômico: visa avançar na promoção da competitividade da RMGV nos cenários nacional e internacional, agregando valor às cadeias produtivas e contribuindo para o desenvolvimento socioeconômico equilibrado da metrópole; 
IV - Eixo Meio Ambiente e Áreas de Riscos: visa ao incremento da qualidade ambiental no cotidiano urbano da metrópole, estabelecendo a política ambiental como de interesse metropolitano, com o objetivo de aproximar os espaços naturais do cidadão, integrar os ativos ambientais da região em sua política de desenvolvimento social e econômico, com especial atenção às áreas sujeitas aos riscos de desastres naturais.

Nessa trilha, "ordenamento territorial", "mobilidade urbana", "desenvolvimento econômico" e "meio ambiente e áreas de risco", entre outros institutos e elementos que poderiam ter sido selecionados pelo legislador estadual criador do Plano de Desenvolvimento Urbano Integrado (PDUI) ora em debate, mostram a importância de existência de um plano urbanístico de maior abrangência, hierarquicamente superior aos planos urbanísticos de menor abrangência, que estabeleça "estratégias e políticas públicas agrupadas", conforme dizeres do próprio caput do Art. 4으, ligadas aos denominados "quatro eixos integradores".

É certo que um longo caminho deverá ser percorrido para a consolidação do Plano de Desenvolvimento Urbano Integrado (PDUI) em todas as regiões metropolitanas do país. Da mesma maneira, é também certo que o pioneirismo e cumprimento do prazo legal inicialmente previsto no Estatuto da Metrópole, conforme já acima afirmado, merece elogios, uma vez que também se sabe que o caminho para a aprovação de uma lei não é simples. E de uma lei com exigências maiores no seu processo legislativo, como no caso dos agora 02 (dois) planos urbanísticos diretamente relacionados e existentes no país, muito menos. Mas nada disso é impeditivo para que o Poder Público aja. E para que os Governos e Administração Pública, genericamente considerada, tomem não apenas as medidas necessárias para a criação e final aprovação de planos urbanísticos, mas também muito mais do que estas citadas medidas, agindo para além de um latente mínimo necessário e envidando todos os esforços para que dia após dia, o Brasil possa crescer com maior atenção destinada às suas inúmeras, vastas e gigantescas áreas e aglomerações urbanas.

\section{CONCLUSÃO}

Até o mês de março de 2018, apenas um Estado membro da Federação brasileira e, frise-se, com relação a uma região metropolitana, aprovou e instituiu seu Plano de Desenvolvimento Urbano Integrado (PDUI). Mais precisamente, o Estado do Espírito Santo e a Região Metropolitana da Grande Vitória (RMGV). Todos os demais Estados brasileiros, assim como suas regiões metropolitanas, ainda continuam carentes de seus Planos de Desenvolvimento Urbano Integrado (PDUI). 
Conforme conclusões ao longo do texto, alguns Estados, com relações a suas respectivas regiões metropolitanas, encontram-se em processos adiantados no que concerne à elaboração e aprovação dos seus Planos de Desenvolvimento Urbano Integrado (PDUI). Entretanto, outros tantos, em fase muito inicial e, ainda a maioria, sem qualquer movimentação condizente, considerando as aproximadas sete dezenas de regiões metropolitanas brasileiras.

Se o Plano Diretor, único plano urbanístico constitucionalmente previsto no Brasil, demorou a ser aceito e entendido, assim como ainda longa estrada tem a percorrer rumo à sua aceitação pela sociedade amplamente considerada, o Plano de Desenvolvimento Urbano Integrado (PDUI) nasce legislativamente com a vantagem de ser não mais o primeiro e único relevante plano urbanístico. Mas, por outro lado, com também um caminho extenso de entendimento, compreensão, aceitação e validação sociais e institucionais a ser trilhado e, sobretudo, com a imaturidade jurídica bem mais intensa do que a já um tanto quanto mitigada em relação ao Plano Diretor, nascido na Constituição de 1988, criado em vários municípios brasileiros por meio de legislações esparsas e, finalmente, melhor regulamentado pelas normas e diretrizes gerais trazidas pelo Estatuto da Cidade.

O ordenamento jurídico brasileiro precisará amortecer a chegada de novos institutos legais, o que deverá, necessariamente, também ocorrer com variados grupos sociais e instituições do país. É o caminho para que se possa, mesmo tímida e minimamente, começar a se celebrar avanços em matéria urbanística e, concomitantemente, ligados à tão rica, vasta, multidisciplinar e robusta área do saber jurídico, englobada, entre outros, mas, principalmente, pelo Direito Urbanístico.

\section{REFERÊNCIAS BIBLIOGRÁFICAS}

AZEVEDO, Sergio de, RIBEIRO, Luiz Cesar de Queiroz, SANTOS JUNIOR, Orlando Alves dos (Org.). Governança democrática e poder local: a experiência dos conselhos municipais no Brasil. Rio de Janeiro: Revan, Fase, 2004.

BARROSO, Luís Roberto. O Direito Constitucional e a efetividade de suas normas. 04. ed. Rio de Janeiro: Editora Renovar, 2000. 
BONIZZATO, Luigi. Propriedade Urbana Privada \& Direitos Sociais: 2a Edição - Revista e Atualizada, incluindo a Lei 13.089/15, que instituiu o Estatuto da Metrópole. Curitiba: Juruá Editora, 2015.

Constituição, Democracia e Plano Diretor, sob o influxo de direitos sociais e de liberdade, políticas estatais e institucionais. Rio de Janeiro: Editora Lumen Juris, 2014.

A Constituição Urbanística e elementos para a elaboração de uma teoria do Direito Constitucional Urbanístico. Rio de Janeiro: Editora Lumen Juris, 2010.

BONIZZATO, Luigi, REIS, José Carlos Vasconcellos dos. Direito Constitucional: questões contemporâneas, clássicas e críticas. Rio de Janeiro: Editora Lumen Juris, 2011.

CAETANO, Marcello. Princípios fundamentais do Direito Administrativo. Coimbra: Livraria Almedina, 1996.

COlOMBO, Guido, FORTUNATO, Pagano, ROSSETTI, Mario. Manuale di urbanistica. 13. ed. Milano: II Sole 24 Hore, 2001.

CORRÊA, Vera Lúcia de Almeida, VERGARA, Sylvia Constant (Orgs.). Propostas para uma gestão pública municipal efetiva. Rio de Janeiro: FGV Editora, 2003.

CORREIA, Fernando Alves. O plano urbanístico e o princípio da igualdade. Coimbra: Almedina, 2001.

FERRAJOLI, Luigi. Principia iuris. Teoria Del diritto e della democrazia. V. I, II e III. Roma-Bari: Editori Laterza, 2007.

Derechos y Garantias: la ley del más débil. 03. ed. Tradução de Perfecto Andrés Ibáñez e Andrea Greppi. Madrid: Editorial Trotta, 2002.

FIALE, Aldo. Compendio di Diritto Urbanistico. 2. ed. Napoli: Edizioni Giuridiche Simone, 1998.

HAMILTON, Alexander, JAY, John, MADISON, James. The Federalist. Cambridge: John Harvard Library, 2009. 
LOPES, Rodrigo. A cidade intencional: o planejamento estratégico de cidades. 02. ed. Rio de Janeiro: Editora Mauad, 1998.

REGIÃO METROPOLITANA DE UMUARAMA E OUTRAS TRÊS DEVEM SER EXTINTAS. [on line] Disponível na Internet via www.URL: <http://www.obemdito.com.br/noticiasumuarama/regiao-metropolitana-de-umuarama-e-outras-tres-devem-ser-extintas/11430/>. Última atualização em 07 de julho de 2017.

RIBEIRO, Luiz Cesar de Queiroz (Org.). Metrópoles: entre a coesão e a fragmentação, a cooperação e o conflito. Rio de Janeiro: FASE, 2004.

SALVIA, Filippo, TERESI, Francesco. Diritto urbanístico. 07. ed. Padova: CEDAM, 2002.

SECRETARIA DE ESTADO DO PLANEJAMENTO. [on line] Disponível na Internet via www.URL: <http://www.spg.sc.gov.br/acoes/18-regionais>. Última atualização em 11 de março de 2018.

SOJA, Edward W. Geografias pós-modernas: a reafirmação do espaço na toeria social crítica. Tradução de Vera Ribeiro. Rio de Janeiro: Jorge Zahar Editor, 1993.

SOUZA, Diana Paula de. Brasil tem três novas regiões metropolitanas. [on line] Disponível na Internet via www.URL: <https://agenciadenoticias.ibge.gov.br/agencia-noticias/2012-agenciade-noticias/noticias/9868-brasil-tem-tres-novas-regioes-metropolitanas.html>. Última atualização em 01ㅇ de fevereiro de 2018.

SOUZA, Marcelo Lopes de. Mudar a cidade: uma introdução crítica ao planejamento e à gestão urbanos. Rio de Janeiro: Editora Bertrand Brasil, 2002.

O desafio metropolitano: um estudo sobre a problemática sócio-espacial nas metrópoles brasileiras. Rio de Janeiro: Editora Bertrand Brasil, 2002.

Trabalho enviado em 02 de abril de 2018

Aceito em 26 de junho de 2018 